\title{
Antioestrogen-mediated cell cycle arrest and apoptosis induction in breast cancer and multiple myeloma cells
}

\author{
Jack-Michel Renoir ${ }^{1,2,3}$, Céline Bouclier ${ }^{1,2,3}$, Amélie Seguin ${ }^{4}$, Véronique Marsaud ${ }^{1,2,3}$ \\ and Brigitte Sola ${ }^{4}$ \\ ${ }^{1}$ CNRS, UMR 8612, Pharmacologie Cellulaire et Moléculaire des Anticancéreux, Faculté de Pharmacie, 5 rue JB Clément, Châtenay-Malabry F-92296, France \\ ${ }^{2}$ Université Paris-Sud, Orsay F-91405, France \\ ${ }^{3}$ IFR 141, Châtenay-Malabry F-92296, France \\ ${ }^{4}$ Biologie moléculaire et cellulaire de la signalisation, EA 3919, IFR 186, Université de Caen-Basse Normandie, 14000 Caen, France \\ (Correspondence should be addressed to J-M Renoir; Email: michel.renoir@u-psud.fr)
}

\begin{abstract}
Antioestrogens (AEs) are synthetic molecules that block proliferation and induce apoptosis in breast cancer (BC) cells, principally by competing with oestradiol for binding to oestrogen receptors. Their antiproliferative activity and their proapoptotic capacity are well documented and a small number of molecules of this class are currently used clinically for the treatment of BC. AEs also inhibit cell cycle progression and/or induce apoptosis in multiple myeloma (MM) cells. Encouraging preliminary results have been obtained with patients and on xenografts with $\mathrm{MM}$, providing a rational basis for the clinical use of AEs. This review focuses on antioestrogen-mediated signalling for blocking targets involved in the cell cycle, survival and apoptosis in both BC and MM cells. Improvement in our understanding of the mechanisms underlying the relationships between these compounds and their targets should lead to more beneficial therapeutic strategies.
\end{abstract}

Journal of Molecular Endocrinology (2008) 40, 101-112

\section{Introduction}

The development of hormonal treatments has led to an extensive search for highly effective and well-tolerated molecules. Antioestrogens (AEs; Fig. 1) are synthetic compounds entirely fulfilling these criteria. They inhibit the activation of two different but related ligand-induced transcription factors of the nuclear receptor superfamily: the oestrogen receptors (ER $\alpha$; Green et al. 1988) and ER $\beta$ (Kuiper et al. 1996, Mosselman et al. 1996). ER $\alpha$ is the master regulator of breast cancer (BC) tumour behaviour and is much more strongly expressed in BC tumours than ER $\beta$ (Dahlman-Wright et al. 2006). It is currently thought that ER $\beta$ represses growth by inhibiting ER $\alpha$-mediated transcriptional activity (Hall \& McDonnell 1999, Liu et al. 2002, Lindberg et al. 2003, Faulds et al. 2004, Strom et al. 2004), and the balance between the levels of ER subtypes appears as an important regulator of the mitogenic activity of 17 beta oestradiol $\left(\mathrm{E}_{2}\right.$; Matthews et al. 2006, Holst et al. 2007). AEs block the binding of $\mathrm{E}_{2}$ to $\mathrm{ER} \alpha$ and inhibit the $\mathrm{E}_{2}$-induced effects mediated by the two ERs. However, this model cannot account for all the effects of AEs. Indeed, it has been shown that some $\mathrm{ER} \alpha$ receptors are located in the cancer cell membrane, facilitating $\mathrm{E}_{2^{-}}$and DNA-independent ER activation through crosstalk with the growth factor-induced activation of cell-surface tyrosine kinase receptors (Moss et al. 1997, Falkenstein et al. 2000, Hanstein et al. 2004). Thus, two different types of signalling may be mediated by $\mathrm{E}_{2}$, with nuclear (genomic) and extranuclear (non-genomic) effects (for reviews see (O’Malley 2005, Song et al. 2006)).

The ER $\beta$ subtype has been identified not only in the mammary gland and both male and female reproductive tissues, but also in the colon, brain, pancreas and haematopoietic cells of the myeloid and lymphoid lineages (Enmark \& Gustafsson 1999, Shim et al. 2003). Several groups have shown that AEs block proliferation and induce apoptosis in multiple myeloma (MM) cells, as in BC cells (Treon et al. 1998, Otsuki et al. 2000, Gauduchon et al. 2005, Olivier et al. 2006). In recent years, we have focused on deciphering the molecular mechanisms by which 
<smiles>CC/C(=C(\c1ccccc1)c1ccc(O)cc1)c1ccccc1</smiles>

4 Hydroxy-tamoxifen<smiles>O=C(c1ccc(OCCN2CCCCC2)cc1)c1c(-c2ccc(O)cc2)sc2cc(O)ccc12</smiles>

Raloxifen<smiles>CC12CCC3c4ccc(O)cc4C[C@H](CCCCCCCCCS(=O)CCCC(F)(F)F)C3C1CCC2O</smiles>

ICI 182,780, Faslodex, Fulvestrant<smiles>CC12C[C@H](c3ccc(OCCCCCCCS(=O)(=O)CCC(F)(F)F)cc3)C3c4ccc(O)cc4CCC3C1CC[C@@H]2O</smiles>

RU58668

Figure 1 Chemical structures of antioestrogens. 4-hydroxy-tamoxifen (4-HT), the active metabolite of tamoxifen and raloxifen belong to the selective oestrogen receptor modulator (SERMs) family. The members of this family act either as $E_{2}$-agonists or -antagonists depending on ER subtype and cell context. ICI 182780 and RU58668 are selective oestrogen receptor down-regulators (SERDs), acting as pure antioestrogens.

AEs, both selective oestrogen receptor modulators (SERMs), such as 4-hydroxy-tamoxifen (4-HT), and selective oestrogen receptor down-regulators (SERDs), such as ICI 182780 (ICI or Faslodex ${ }^{\circledR}$ ) and RU58668 (RU), arrest the cell cycle and/or induce apoptosis in hormone-dependent BC and MM cells. We provide here a review of some of our data. Despite the use of different molecular partners, the signalling pathways involved in cell cycle arrest and the induction of apoptosis by these AEs are similar regardless of the type of cancer cell considered.

\section{Oestrogens and antioestrogen effects in mammary gland cells}

\section{Growth and anti-apoptotic properties of oestrogens}

ERs are the predominant target of $\mathrm{E}_{2}$ in the mammary gland. We will not describe the mechanism of action of these transcription factors in detail here, because many reviews have covered the latest discoveries concerning nuclear and membrane ER activities and clinical studies (Osborne \& Schiff 2005, Heldring et al. 2007, Jordan \& Brodie 2007, Lonard \& O'Malley 2007, Popov et al. 2007). In the mammary gland, $\mathrm{E}_{2}$ promotes cell proliferation in both normal and transformed epithelial cells by modifying the expression of hormoneresponsive genes involved in the cell cycle and/or programmed cell death. In ER-positive human BC MCF-7 cells, the principal action of $\mathrm{E}_{2}$ is the induction of proliferation through the stimulation of G1- to S-phase transition. This induction is associated with the rapid and direct up-regulation of c-myc, which controls cyclin D1 expression, the activation of cyclin-dependent kinase $(\mathrm{Cdk})$ and the phosphorylation of retinoblastoma protein (pRb; Fig. 2; Altucci et al. 1996, Foster \& Wimalasena 1996, Hurd et al. 1997, Prall et al. 1997, Doisneau-Sixou et al. 2003). Evidence for a key role of c-myc in $\mathrm{E}_{2}$ action has been obtained from experiments showing that antisense oligonucleotides inhibit $\mathrm{E}_{2}$ stimulated BC cell proliferation (Watson et al. 1991) and that the induction of c-Myc in AE-arrested cells can mimic the effects of $\mathrm{E}_{2}$ by reinitiating cell cycle progression (Prall et al. 1998). The mitogenic and anti-apoptotic activities of $\mathrm{E}_{2}$ are combined through the activation of $b c l-2$ gene expression and the production of smaller amounts of p53 and caspase-3 in primary cultures of normal mammary epithelial cells (Somai et al. 2003). Moreover, $\mathrm{E}_{2} / \mathrm{ER} \alpha$ complexes bind directly to a cAMP-response element and a more distal Sp1 site on the cyclin D1 promoter, leading to an increase in cyclin D1 mRNA levels (Altucci et al. 1996, Prall et al. 


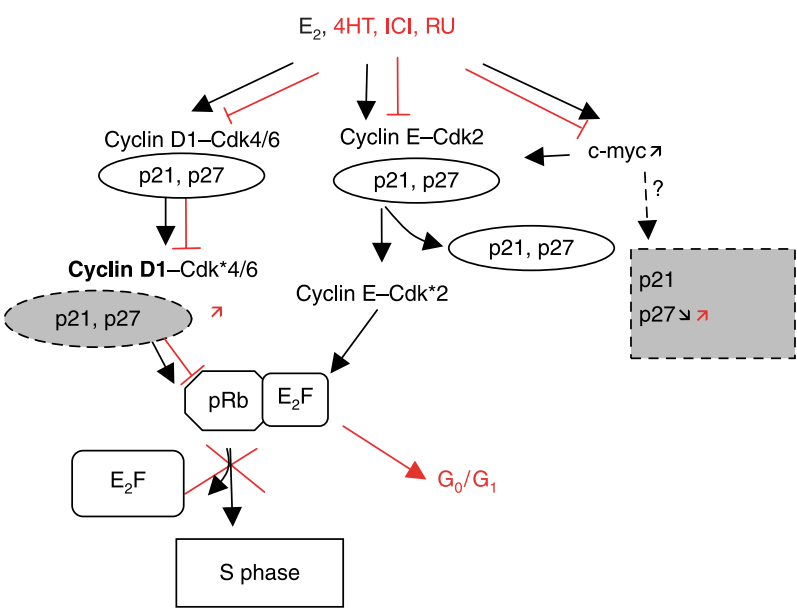

Figure 2 Schematic illustration of the activities of oestradiol and antioestrogens in MCF-7 cells. Following $E_{2}$ treatment, a rapid transcription-mediated increase $(\nearrow)$ in c-myc expression occurs, facilitating cyclin $\mathrm{E}-\mathrm{Cdk} 2$ activation and entry into S phase. Concomitantly, $E_{2}$ down-regulates ( $)$ p $21^{\text {Cip1 }}$ and p27 $27^{\text {Kip1 }}$ and increases cyclin D1 levels. The formation of complexes containing Cdk4 and sequestrating Ckis is enhanced. Ckis levels are downregulated upon c-myc expression. All these events initiate the phosphorylation of pRb. Cyclin D1 in bold typeface: increase in cyclin D1 levels with activated cyclin-Cdk complexes; *increase in Cdk activity. In grey boxes, low levels of Cki. In black, $E_{2}$-mediated effects. In red, AE-mediated inhibition leading to cell cycle arrest in G0/G1. Refer to text for details and references.

1997, Sabbah et al. 1999, Castro-Rivera et al. 2001). ER $\beta$ competes with $\mathrm{ER} \alpha$ in the induction of cyclin D1 transcription (Liu et al. 2002).

$\mathrm{E}_{2}$ also rapidly activates cyclin $\mathrm{E}-\mathrm{Cdk} 2$ complexes and, by relieving the inhibition mediated by the natural Cdk inhibitor (Cki) p21 ${ }^{\text {Cip1 }}$, accelerates the G1 to S transition (Foster \& Wimalasena 1996, Planas-Silva \& Weinberg 1997, Prall et al. 1997, 2001). Another key element of the regulatory apparatus of the G1 phase is Cki p27 $7^{\mathrm{Kip} 1}$, which inhibits both Cdk2 activity in G0 and early G1 and acts as an assembly factor for cyclin D-Cdk4/ 6 complexes in early G1 (see Sherr \& Roberts 1999, for a review). The functional expression of p2 $7^{\text {Kip1 }}$ is essential for normal proliferative responses in the mammary epithelium (Muraoka et al. 2001). . E 2 activates cyclin E-Cdk2 complexes in MCF-7 cells, and the G1-S transition is associated with a decrease in the levels and activities of $\mathrm{p} 27^{\mathrm{Kip} 1}$ and $\mathrm{p} 21^{\mathrm{Cip} 1}$ (Foster \& Wimalasena 1996, Prall et al. 1997, Foster et al. 2001; Fig. 2). Moreover, $\mathrm{E}_{2}$ up-regulates Bcl-2 protein levels in MCF-7, T47-D and ZR-75-1 BC cells (Gompel et al. 2000).

\section{Growth inhibition of AEs}

The growth-inhibiting effects of AEs in ER-positive BC cells and normal epithelial mammalian cells result from cell cycle arrest in the G0/G1 phase (Musgrove et al. 1993, Doisneau-Sixou et al. 2003, Somai et al. 2003, Jamerson et al. 2004). This antiproliferative activity is associated with the inhibition of Cdk activity and a decrease in $\mathrm{pRb}$ phosphorylation (Watts et al. 1995). In addition to the cell cycle regulator c-Myc (Jamerson et al. 2004), AEs target cyclin D1, cyclin E, p21 ${ }^{\mathrm{Cip} 1}$ and $\mathrm{p} 27^{\mathrm{Kip} 1}$ (Caldon et al. 2006). Both Cki molecules are weakly expressed in mammary cells, such as BC cells, but exposure to 4-HT, ICI or RU strongly increases their expression (Cariou et al. 2000, Slingerland \& Pagano 2000, Foster et al. 2003). Inhibition of the expression of either $\mathrm{p} 21^{\mathrm{Cip} 1}$ or $\mathrm{p} 27^{\mathrm{Kip} 1}$ with antisense oligonucleotides maintains Cdk2 in an active state and prevents AE-mediated G1 blockade (Cariou et al. 2000, Carroll et al. 2000). AEs from different classes have different effects on ER $\alpha$-positive BC cells: 4-HT blocks these cells in the G1 phase, whereas ICI and RU render these cells quiescent (Carroll et al. 2000, 2003; Fig. 2).

\section{Pro-apoptotic activity of AEs}

Mitochondria are known to play an integral role in apoptosis, and it was demonstrated that tamoxifen (Tam) induces increased rate of apoptosis after long-term treatment (Thiantanawat et al. 2003). Caspase-3 and caspase-7 are the most commonly studied effector caspases. When activated, they directly target proteins involved in cell integrity and are responsible for the final stage of cell death (Strasser et al. 2000). Specific caspase activation cascades are dependent on apoptotic stimuli (Riggins et al. 2005a). T47-D and ZR-75-1 cells contain caspase-3 that is absent from MCF-7 cells (Janicke et al. 1998). In MCF-7 cells, apoptosis proceeds via the sequential activation of caspase-7 and caspase- 6 (Table 1). However, Tam increases the activity of caspases-3 in ER-negative BC cells (Mandlekar et al. 2000) and of caspase-9, caspase-6 and caspase-7 in MCF-7 cells (Thiantanawat et al. 2003) with concomitant down-regulation of Bcl-2 and up-regulation of Bax. In T47D cells, Tam treatment activates caspase-3 (Ellis et al. 2003). It was also shown that in MCF-7 cells and rat mammary tumours, well known to resemble human BC tumours, Tam causes activation of caspase- 8 , a caspase normally related to membrane death receptor activation (Mandlekar et al. 2000). Indeed, caspase inhibitor z-VAD-fmk completely blocks Tam-induced apoptosis (Mandlekar et al. 2000). Although intriguing, these data suggest that AEs may affect both intrinsic (via caspase-9 activation) and extrinsic (via caspase-8 activation) apoptotic pathways.

Both SERMs like Tam and SERDs like ICI and RU induce moderate apoptosis in MCF-7 cells (Kandouz et al. 1999, Gompel et al. 2000) accompanied by poly-(ADPribose) polymerase (PARP) cleavage. These apoptotic properties are observed at micromolar concentrations of AEs in all BC cells, whereas cell cycle blockade occurs at nanomolar concentrations of AEs, suggesting that these two processes are independent and triggered by separated pathways. It was recently shown that 
Table 1 Comparison of the apoptotic effects of selective oestrogen receptor modulators (SERMs) and selective oestrogen receptor down-regulators (SERDs) in breast cancer and multiple myeloma cells

BC cells

\begin{tabular}{ll}
\hline MCF-7 \\
\hline 4-HT & $\mathrm{RU}$ \\
\hline
\end{tabular}

Death ligand/receptor TNF/TNFR TRAIL/DR4/5 ND

FasL/Fas

Bcl-2 family

$\mathrm{Bcl}-2$

Bcl-XL

Bax

Bik

Mcl-1

Caspase

Caspase-3

Caspase-4

Caspase-7

Caspase-8

Caspase-9
ND

$\nearrow$

$\searrow$

ND

$\rightarrow$ (a)

$\rightarrow$ (a)

$\rightarrow$ (a)

$\mathrm{ab}$

ND

$\nearrow$

$\nearrow$

$\nearrow$
T47-D

4-HT

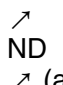

$\nearrow(\mathrm{a})$

$\searrow$ (b)

$\mathrm{ND}$

$\nearrow$ (b)

$s<$ (b)

$a b$

ND

ND

ND

$N D$
$N D$
$\nearrow$
$\searrow$
$N D$
$\rightarrow(a)$
$N D$
$N D$

$\nearrow$

ND

ND

ND

ND
MM cells

\begin{tabular}{|c|c|c|}
\hline RPMI & & LP-1 \\
\hline 4-HT & $\mathrm{RU}$ & 4-HT \\
\hline
\end{tabular}

RU

ND ND

$\nearrow$ (a)

$\stackrel{\searrow}{\text { ND }}$

$\rightarrow(\mathrm{a})$

ND

$s<$ (b)

$\nearrow(\mathrm{a})$

ND

ND

ND

ND

$\mathrm{ND}$
$\rightarrow(\mathrm{a})$
$\rightarrow$
$\rightarrow$
$\rightarrow$
$\rightarrow$
$\mathrm{ND}$
$\mathrm{ND}$
$\nearrow$
$\mathrm{ND}$
$\mathrm{ND}$
$\nearrow$
$\nearrow$

$\mathrm{ND}$
$\rightarrow(\mathrm{a})$
$\rightarrow$
$\rightarrow(\mathrm{a})$
$\rightarrow(\mathrm{a})$
$\mathrm{ND}$
$8 \times$
$\nearrow$
$\nearrow$
$\mathrm{ND}$
$\nearrow$
$\nearrow$

$\mathrm{ND}$
$\rightarrow(\mathrm{a})$
$\rightarrow$
$\rightarrow$
$\rightarrow$
$\rightarrow$
$\mathrm{ND}$
$\searrow$
$\nearrow$
$\mathrm{ND}$
$\mathrm{ND}$
$\nearrow$
$\nearrow$

ND

$\rightarrow$ (a)

$\rightarrow(\mathrm{a})$

$\rightarrow$ (a)

$\rightarrow$ (a)

$\mathrm{ND}$
$\searrow(\mathrm{a})$

$\nearrow$

$\overrightarrow{N D}$

ND

$\nearrow$, enhanced or activated for caspase; \, decreased; $\rightarrow$, identical; $\diamond<$, cleaved; ND, not determined; (a), our unpublished results; (b), obtained with ICl; ab, absent.

micromolar concentrations of ICI, 4-HT and raloxifen but also $\mathrm{E}_{2}$ induce cell death due to the formation of reactive oxygen species (ROS), triggering classical caspase-dependent apoptosis (Mandlekar et al. 2000, Obrero et al. 2002, Kallio et al. 2005). Tam-induced production of ROS associated with release mitochondrial cytochrome $c$ appears responsible for the early apoptotic effects of Tam. In addition, Tam-induced rapid death of MCF-7 cells is mediated by extracellular signal-regulated kinase signalling that can be abrogated by $\mathrm{E}_{2}$ but not by ICI in an ER-independent mechanism (Zheng et al.

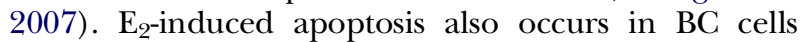
resistant to long-term oestrogen deprivation (aromatase inhibitors) and to AEs (Gottardis et al. 1988, Lewis et al. 2005) and $\mathrm{E}_{2}$ treatment may constitute a new clinical strategy following exhaustive antihormone therapy (Jordan et al. 2005).

The $\mathrm{E}_{2}$-responsive cell lines MCF-7, T47-D and ZR75.1 all express the surface tumour necrosis factor (TNF), TRAIL and Fas-L receptors, the key mediators of the extrinsic apoptotic pathway the ligand-dependent activation of which generally results in rapid cell death. Unlike $E_{2}$, Tam up-regulates Fas-L expression (Nagarkatti \& Davis 2003). However, in MCF-7 cells subjected to long periods of $\mathrm{E}_{2}$ deprivation, $\mathrm{E}_{2}$-induced apoptosis is correlated with Fas-L expression (Song \& Santen 2003). TNF-mediated apoptosis in MCF-7 cells can be abolished by $\mathrm{E}_{2}$ treatment, via an increase in production of the antiapoptotic mediator Bcl-2 (Burow et al. 2001). Both ICI and Tam enhance TNF-induced cell death, by triggering $\mathrm{TNF}$ receptor production and expression at the cell surface (Smolnikar et al. 2000). Thus, significant crosstalk occurs between the TNF- and AE-induced apoptosis pathways (Table 1).

Contradictory data have been published regarding the effects of AEs on the members of the Bcl-2 family. $\mathrm{E}_{2}$ has been shown to up-regulate the anti-apoptotic Bcl-2 protein in oestrogen-dependent BC cells (Gompel et al. 2000), an effect counteracted by both Tam and pure AEs (Kandouz et al. 1999, Zhang et al. 1999, Ameller et al. 2003, Somai et al. 2003, Thiantanawat et al. 2003). In MCF-7 cells, $\mathrm{E}_{2}$ has been shown to decrease levels of the pro-apoptotic Bak protein, whereas aromatase inhibitors or AEs have been shown to increase Bak levels (Leung et al. 1998, Thiantanawat et al. 2003). However, other studies have reported no effects of oestrogens or AEs on levels of Bax or Bak protein (Kandouz et al. 1999, Zhang et al. 1999, Gompel et al. 2000). There is therefore no clear consensus concerning the roles of these molecules in AE-mediated apoptosis. Bcl-XL is produced in small amounts, unaffected by AEs in BC cells. The pro-apoptotic protein Bik is down-regulated by $\mathrm{E}_{2}$ and up-regulated by ICI, but not by the SERMs 4-HT and raloxifen (Frasor et al. 2003, Hur et al. 2004, Frasor et al. 2006).

Thus, in BC cells, the pro-apoptotic activity of AEs is triggered through multiple pathways that are whether dependent or independent on ER signalling.

\section{p53}

The tumour suppressor p53 is inactivated in 30\% of all BCs. Together with $\mathrm{p} 63$ and p73, two other proteins from 
the same family, p53 is a global regulator of cell cycle checkpoints and apoptosis. MCF-7 and ZR.75.1 cells contain wild-type p53, whereas T47-D cells produce a mutated form unable to bind DNA. As p53-regulated target genes, such as those encoding $\mathrm{p} 21^{\mathrm{Cip} 1}$ and the proapoptotic Bax protein, are activated in response to various stimuli, and since $\mathrm{ER} \alpha$ binds directly to p53 (Liu et al. 2006, Sayeed et al. 2007), it was suggested that p53 is involved in the response to AEs in BC cells. However, the effects of AEs on p53 remain unclear. It has been reported that the depletion of Tam and $\mathrm{E}_{2}$ decreases p53 levels and that Faslodex can reverse the $\mathrm{E}_{2}$-mediated increase in p53 levels in T-47D cells (Dinda et al. 2002). The group responsible for this study also showed that $\mathrm{E}_{2}$ and Tam induce the transcriptional activity of the P1 promoter of p53 in MCF-7 cells, whereas Faslodex does not (Hurd et al. 1997). These data contrast with data from other studies reporting no change in p53 levels in response to Tam, despite the significant induction of apoptosis and $\mathrm{pRb}$ dephosphorylation (Fattman et al. 1998, Zhang et al. 1999). These differences may be due to the subcellular distribution of p53 within cells (Molinari et al. 2000, Lilling et al. 2002). Furthermore, the product of the $M d m 2$ oncogene, which is overexpressed in various cancers, and encodes an E3 ubiquitin ligase, regulates the stability of $\mathrm{ER} \alpha$ by forming a ternary complex with p53 (Duong et al. 2007). In turn, p53 and $\mathrm{Mdm} 2$ regulate the $\mathrm{E}_{2}$-dependent down-regulation of $\mathrm{ER} \alpha$ and, probably, susceptibility to AE (Duong et al. 2007). Indeed, since ER $\alpha$ inhibits p53-mediated transcriptional repression (Sayeed et al. 2007), it can be emphasised that $\mathrm{AE}$ induces apoptosis in BC cells by, at least in part, relieving the inhibitory activity of $\mathrm{ER} \alpha$ on p53 activity.

\section{Survival proteins}

The deregulation and inappropriate activation of phosphoinositol-3-kinase (PI3K) signalling and its downstream targets, Akt and nuclear factor- $\kappa \mathrm{B}$ (NF$\kappa \mathrm{B})$ have been linked to cancers (Luo et al. 2003). The transcriptional activity of $\mathrm{ER} \alpha$ is activated by constitutively activated Akt independently on the presence of $\mathrm{E}_{2}$ but in a PI3K-dependent manner since the PI3K inhibitor wortmanin inhibits both phosphorylation (Ser-167) and activation of $\mathrm{ER} \alpha$ (Sun et al. 2001). Such activity is abolished by ICI but not completely by Tam, implicating that Akt-activated $\mathrm{ER} \alpha$ contributes to Tam resistance (Michalides et al. 2004, Riggins et al. $2005 a, b)$. Moreover, the p85 subunit of PI3K binds to $\mathrm{E}_{2}$-free $\mathrm{ER} \alpha$ (Sun et al. 2001) and the overexpression of Akt protects against Tam-induced apoptosis (Campbell et al. 2001). However, the role of Akt in BC cells is still unclear: for example, in MCF-7 and MDA-MB-231 cells, $\mathrm{E}_{2}$ induces $\mathrm{PI} 3 \mathrm{~K} / \mathrm{Akt}$ activity via an ER-independent signalling pathway that is not affected by AEs (Tsai $e t$ al.
2001). However, Akt must be considered as a target of choice in BC therapy since its suppression prevents endocrine therapy resistance (Glaros et al. 2006).

The NF- $\kappa \mathrm{B}$ family of transcription factors controls various aspects of the immune system. Among the NF- $\kappa \mathrm{B}$ proteins, some possess a Rel homology domain (RHD), such as RelA (also named p65), cRel and RelB, whereas others such as the $\mathrm{p} 105 / \mathrm{p} 50$ and the $\mathrm{p} 100 / \mathrm{p} 52$ do not. They form hetero-complex proteins by associating with inhibitors $(\mathrm{I} \kappa \mathrm{B})$ of NF- $\kappa \mathrm{B}$, which bind to and inhibit DNA binding of the RHDs (Hayden \& Ghosh 2004). These complexes are activated through the activation of an externally activated $\mathrm{I} \kappa \mathrm{B}$ kinase that phosphorylates $\mathrm{I} \kappa \mathrm{B}$, leading to its proteasomemediated degradation and enabling NF-kB-mediated transcription following nuclear translocation. As shown

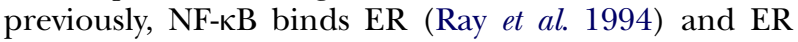
inhibits NF- $\mathrm{K}$ pathway by interacting at various steps of the activation cascade (see Kalaitzidis \& Gilmore 2005 and references herein). NF- $\mathrm{BB}$ activity is repressed by $\mathrm{E}_{2}$ and AEs (Nakshatri et al. 1997, Pratt et al. 2003). Members of the NF- $\kappa \mathrm{B} /$ Rel family form dimers that regulate the transcription of genes encoding regulators of proliferation (c-myc and cyclin D1) and inhibitors of apoptosis (Chen \& Greene 2004). According to several observations, NF- $\kappa \mathrm{B}$ activity is important for mammary carcinogenesis. Several reports have indicated that SERMs (like Tam and raloxifen) as well as SERDs (like ICI) inhibit the NF- $\mathrm{B}$ activity in various cell types (see Biswas et al. 2005 for a review). Thus, most results suggest that inhibiting the NF- $\kappa \mathrm{B}$ pathway in BC could have therapeutic effects principally in Tam-resistant tumours treated with $\mathrm{E}_{2}$ (Jordan 2004) or ICI (Riggins et al. $2005 a, b)$.

\section{Effects of oestrogens and AEs in MM}

\section{Expression of oestrogen receptors}

Oestrogens influence the differentiation, proliferation and survival of haematopoietic cells of the B lineage (Smithson et al. 1998, Medina et al. 2000, Grimaldi et al. 2002) and increase the number of plasma cells and the capacity of these cells to synthesise immunoglobulins (Molina et al. 1999). It is therefore not surprising that normal plasma cells and plasma cells from tumours both produce oestrogen receptor mRNA and protein. Transcripts for both ER subtypes are present in MM cell lines (Fig. 3; Otsuki et al. 2000), together with protein isoforms (Treon et al. 1998, Gauduchon et al. 2005, Maillard et al. 2006, Olivier et al. 2006). However, these proteins are expressed in small amounts and are difficult to detect by immunoblotting. This is particularly true for ER $\beta$, for which the quality of commercially available antibodies is low. In contrast to previous 


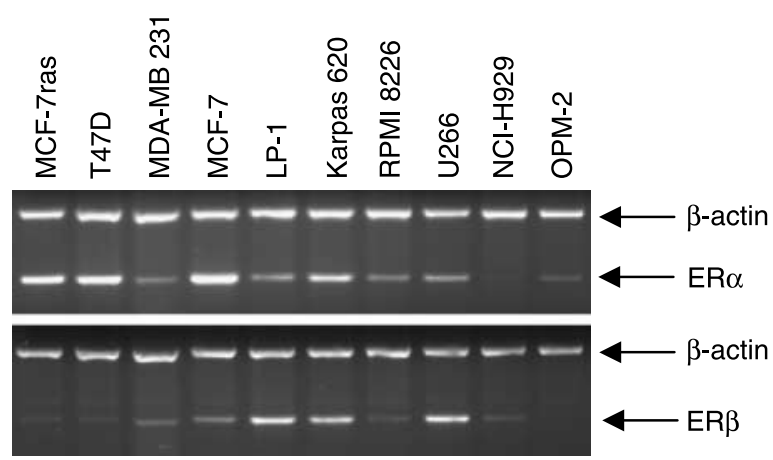

Figure 3 Oestradiol receptors in breast cancer and multiple myeloma cells. BC (MCF-7ras, T47D, MDA-MB231, MCF-7) and MM (LP-1, Karpas 620, RPMI 8226, U266, NCl-H929, OPM-2) cells were switched to phenol red-free media containing $10 \%$ charcoal-dextran stripped fetal calf serum 3 days before total RNA isolation with Trizol reagent (Invitrogen). Purified RNA was reverse transcribed with M-MuLV reverse transcriptase (Invitrogen), according to the manufacturer's instructions. PCR was carried out with Platinum Taq polymerase (Invitrogen). The primer sequences were as follows: $\beta$-actin (forward: $5^{\prime}$-tgacggggtcacccacactgtgcccatcta-3', reverse: $5^{\prime}$-ctagaagcatttgcggtggacgatggaggg-3'), ER $\alpha$ (forward: $5^{\prime}$-gtggcctcgttttagtc- $3^{\prime}$, reverse: $5^{\prime}$-tcacctgtgagagaacag- $3^{\prime}$ ), ER $\beta$ (forward: $5^{\prime}$-tcacatctgtatgcggaacc- $3^{\prime}$, reverse: $5^{\prime}$ cgtaacacttccgaagtcgg- $\left.3^{\prime}\right)$.

reports (Olivier et al. 2006), we found that the levels of $\mathrm{ER} \alpha$ and $\beta$ in MM cells never reached those in MCF-7 cells (Gauduchon et al. 2003, 2005). As a result, hormone-binding detection assays based on the use of tritiated high-affinity oestrogens have always been unsuccessful in our hands (unpublished data).

\section{Effects of oestrogens and AEs on MM cell proliferation}

$\mathrm{E}_{2}$ and AEs are anti-proliferative in MM cells (Treon et al. 1998, Otsuki et al. 2000, Gauduchon et al. 2005, Olivier et al. 2006). At high concentrations $(0.5$ to $50 \mu \mathrm{M})$, AEs arrest the cell cycle in MM cells at the G1 (Gauduchon et al. 2005, Table 2) or the G2 phase (Olivier et al. 2006) depending on the type of AE used. However, in all cases,

Table 2 Antioestrogen-mediated cell cycle arrests and induction of apoptosis in multiple myeloma cells

\begin{tabular}{|c|c|c|c|}
\hline & 4-HT & RU & $\mathrm{ICI}$ \\
\hline U266 & $\begin{array}{l}\text { G1 arrest + } \\
\text { apoptosis }\end{array}$ & No response & nd \\
\hline RPMI 8226 & $\begin{array}{l}\text { G1 arrest+ } \\
\text { apoptosis }\end{array}$ & Apoptosis & Apoptosis \\
\hline NCl-H929 & $\begin{array}{l}\text { G1 arrest + } \\
\text { apoptosis }\end{array}$ & Apoptosis & Apoptosis \\
\hline $\begin{array}{l}\text { OPM-2 } \\
\text { Karpas } 620 \\
\text { LP-1 }\end{array}$ & $\begin{array}{l}\text { No response } \\
\text { No response } \\
\text { G1 arrest+ } \\
\text { apoptosis }\end{array}$ & $\begin{array}{l}\text { G1 arrest } \\
\text { No response } \\
\text { G1 arrest }\end{array}$ & $\begin{array}{l}\text { G1 arrest } \\
\text { nd } \\
\text { G1 arrest }\end{array}$ \\
\hline
\end{tabular}

nd, not determined. cell cycle arrest is mediated by the down-regulation of c-myc followed by the up-regulation and redistribution of $\mathrm{p} 21^{\mathrm{Cip} 1}$ and $\mathrm{p} 27^{\mathrm{Kip} 1}$ within the cyclin $\mathrm{D} / \mathrm{E} / \mathrm{Cdk}$ complexes, leading to the hypophosphorylation of $\mathrm{pRb}$ (Gauduchon et al. 2005, Olivier et al. 2006, Table 2). A similar situation is observed in BC cells, except that the mediators of AE-mediated cell cycle arrest appear to be cell specific (Sola \& Renoir 2007; Fig. 4).

\section{Effects of AEs on the apoptosis of MM cells}

In addition to their anti-proliferative activity, AEs also trigger MM cell apoptosis at micromolar concentrations (Table 2; Treon et al. 1998, Otsuki et al. 2000, Gauduchon et al. 2005, Olivier et al. 2006). The fact that U266 and Karpas 620 cell lines are listed as not responsive to RU in the face of being ER positive (Fig. 3) may be due to an insufficient (or no) ER protein expression despite the presence of the mRNAs. In agreement with that, using western blot analysis, we did not see the ER protein in Karpas 620 cells (Gauduchon et al. 2005). The lack of AE response could be also due to the absence of co-activators or overexpression of co-repressors as suggested previously (Shim et al. 2003, Shim et al. 2006, Sola \& Renoir 2006). Moreover, the response to 4-HT may be attributable to the production of ROS at micromolar 4-HT concentration.

Cell cycle arrest and apoptosis induction are independent phenomena occurring simultaneously following the treatment with 4-HT and RU or ICI (Gauduchon et al. 2005). AEs activate the mitochondrial intrinsic death pathway (Treon et al. 1998, Otsuki et al. 2000, Gauduchon et al. 2005, Olivier et al. 2006) and may also activate the endoplasmic reticulum death pathway, according to plasma cell physiology. Following the AE-induced apoptotic signal, cytochrome $c$ is released from the mitochondria and activates caspase-9 or caspase- 4 and then caspase-3 (Fig. 5). Apoptosis signalling is amplified by the recruitment of caspase- 8 and the cleavage of Bid (Maillard et al. 2006), but does not require the extrinsic death receptor pathways mediated by Fas/FasL and DR4/5/TRAIL (our unpublished data).

\section{Effects of AEs on MM survival signalling}

MM cells display constitutive activation of survival signalling pathways, including the Ras/mitogen-activated protein kinase (MAPK), Janus kinase (Jak)/signal transducer and activator of transcription (STAT), NF- $\mathrm{B}$, phosphoinositol-3-kinase (PI3K)/Akt pathways (Bommert et al. 2006). To be effective, anti-myeloma agents must therefore target one or several of these pathways. Moreover, the ability to inhibit survival pathways seems to be essential for the treatment of MM resistant to conventional drugs (Hideshima et al. 2007). 


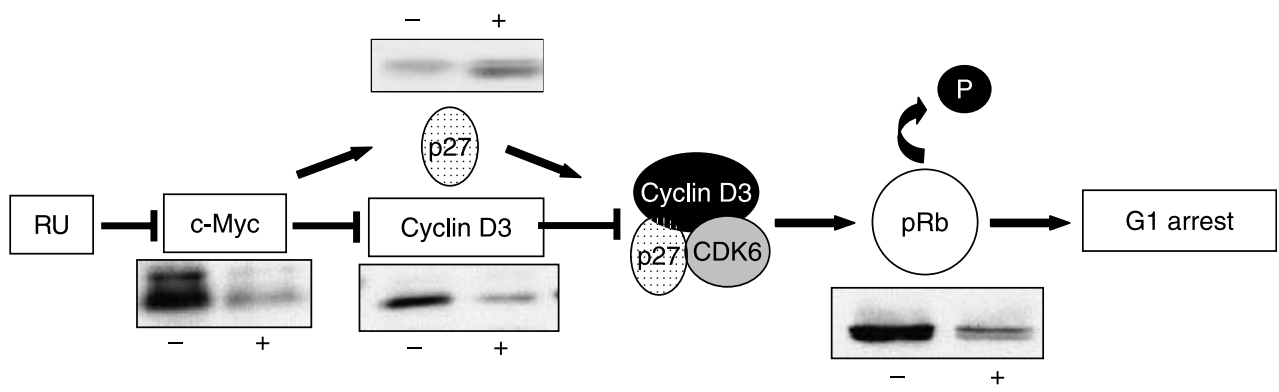

Figure 4 Mechanism of cell cycle arrest in multiple myeloma cells. Cultured LP-1 MM cells were treated with $10 \mu \mathrm{M} \mathrm{RU}(+)$ for $24 \mathrm{~h}$ or left untreated $(-)$ and harvested. Total proteins were extracted, separated by SDS-PAGE, transferred onto membranes then incubated with various antibodies (anti-c-Myc, antip27 ${ }^{\text {Kip1 }}$, anti-cyclin D3, anti-phospho-pRb antibodies). In MM cells, RU down-regulates c-Myc, its primary target, and consequently cyclin D3. In the mean time, there is an up-regulation of the cki p27 Kip1 that binds the cyclin D3/CDK6 complexes. Finally, the inhibition of cdk activity leads to the hypophosphorylation of $\mathrm{pRb}$ and the cell cycle arrest at the G1 phase.

As in some BC cells, it has been shown that the NF- $\mathrm{B}$ p65 subunit is associated with $\mathrm{ER} \alpha$ in the nucleus of MM cell lines although weakly. Upon raloxifen treatment, there is a transient increase in the $\mathrm{p} 65 / \mathrm{NF}-\mathrm{kB}$ interaction and simultaneously a loss of p65 binding on specific gene promoters such as mip- $1 \alpha$ (Olivier et al. 2006). We do not have evidence of any interaction between ER $\alpha$ and NF- $\kappa \mathrm{B}$ subunits in MM cells after RU treatment. Nevertheless,

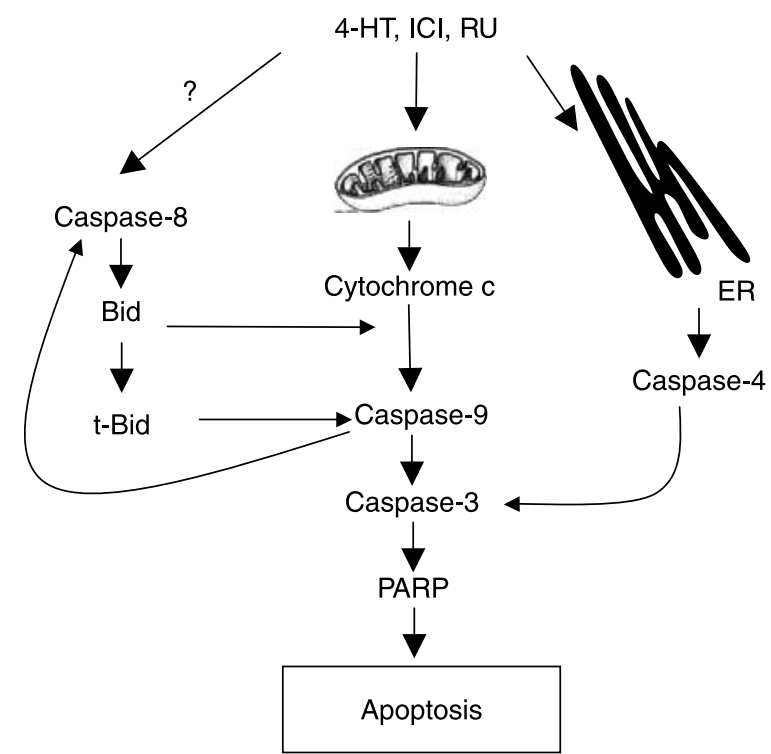

Figure 5 Schematic illustration of the apoptotic pathways activated by antioestrogens in breast cancer and multiple myeloma cells. At micromolar concentrations, AEs activate the intrinsic mitochondrial pathway by inducing the release of cytochrome $c$ and the successive activation of caspase- 9 and caspase- 3 in MM cells (replaced by caspase-6/7 in MCF-7 cells), leading to the cleavage of PARP. In MM cells, RU and ICl also induce apoptosis by activating caspase-4, which, in turn activates caspase-3. Finally, the activation of caspase8 leads to the cleavage of Bid, resulting in the amplification of caspase- 9 activation, further increasing the level of apoptosis. ER, endoplasmic reticulum.
RU induces an inhibition of I $\kappa \mathrm{B}$ kinase activity in RPMI 8226 cells that undergo apoptosis (Fig. 6) and inhibits p65 binding on its DNA target (data not shown). RU also interferes with the STAT3 and Akt pathways by modulating the phosphorylation of signal transducers (Fig. 6). However, the demonstration that the inhibition of these survival pathways is necessary for apoptosis triggering needs some additional work.

\section{Effects of AEs in MM xenografts}

Although not reproducing the exact human pathology, a commonly used model using s.c. injection of RPMI 8226 cells in nude mice was developed (Chauhan et al. 2002, Cuendet et al. 2004). This type of tumour preserves neo-angiogenic characteristics necessary for the development of the disease. Using a stealth liposomal delivery system, we have demonstrated that both RU (Maillard et al. 2005, 2006) and 4-HT (manuscript in preparation) induced a decrease of RPMI 8226 tumour growth. In addition, AE-targeted to solid tumours by delivery systems such as those generated for RPMI 8226 (Maillard et al. 2006) and MCF-7 xenografts induce strong anti-angiogenesis, potentiating the anti-proliferative and apoptotic activities of AEs (Renoir et al. 2006).

\section{Conclusions}

These data demonstrate that, in ER-positive BC and $\mathrm{MM}$ cell lines, both types of $\mathrm{AE}$ arrest the cell cycle and/or induce apoptosis via two independent and separate but similar pathways. Indeed, AEs initially target c-myc and the cell cycle machinery, but cyclin D3 and $\mathrm{p}^{27^{\mathrm{Kip} 1}}$ in MM cells replacing the cyclin D1 and $\mathrm{p} 21^{\mathrm{Cip} 1}$ targeted in $\mathrm{BC}$ cells. AEs trigger the mitochondrial intrinsic death pathway in BC cells and 


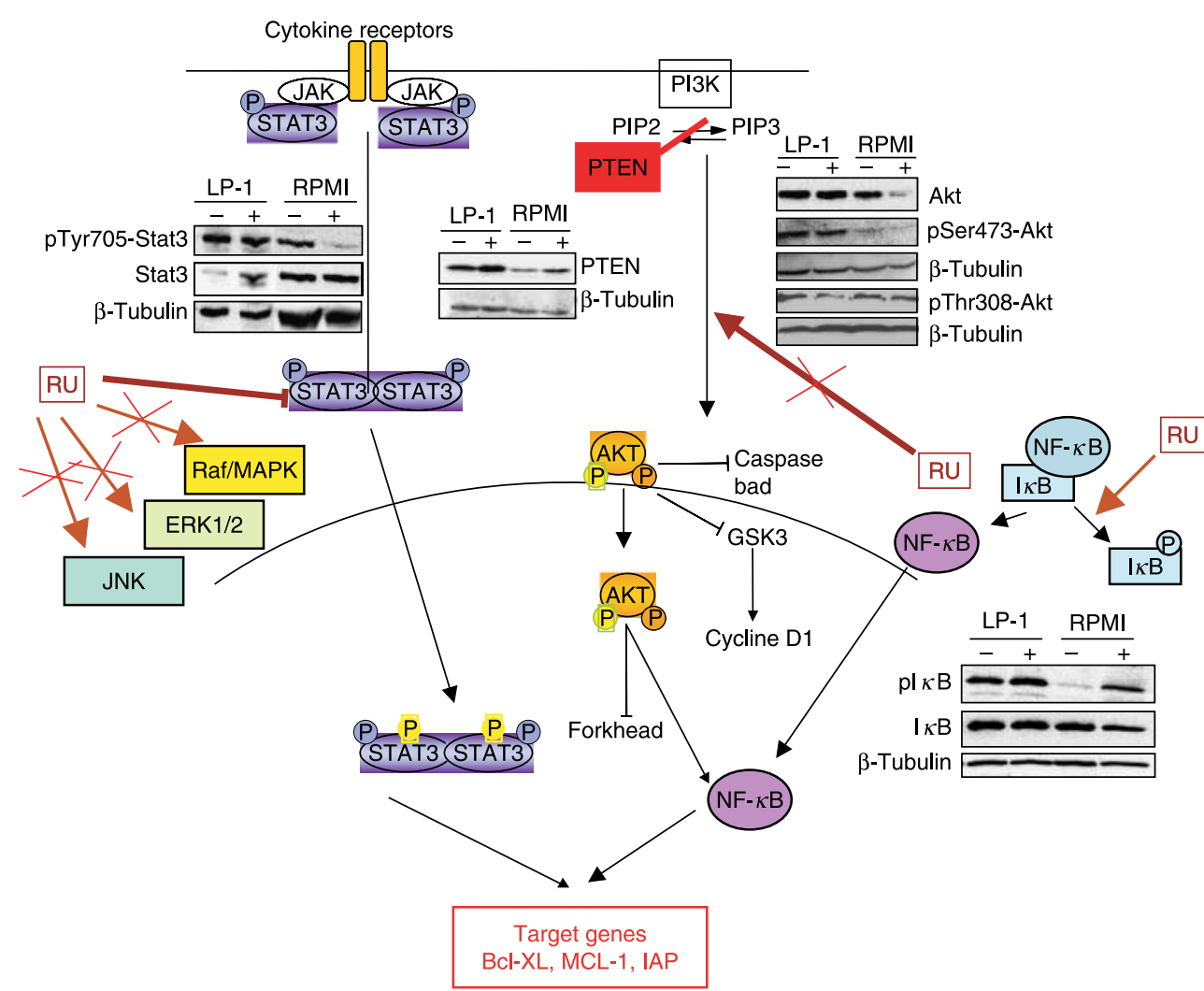

Figure 6 Effects of RU on survival pathways activated in MM cells. MM cells are characterised by the constitutive activation of pathways involved in survival signalling: PI3K/Akt, Jak/Stat3, Ras/MAPK or $\mathrm{NF}-\kappa \mathrm{B}$. This is illustrated by the constitutive phosphorylation of proteins involved in the signalisation cascade. Using phospho-specific antibodies, we analysed the effects of RU on two MM cell lines: LP-1 and RPMI 8226. RU treatment of LP-1 cells blocks cell cycle but has no effects on cell death; by contrast, RU induces RPMI 8226 cell apoptosis but had no effects on cell cycle. The Akt pathway is activated in both cell lines. In LP-1 cells, RU has no effects on pAkt (Ser473 and Thr 308) or the phosphatase PTEN. In RPMI 8226 cells, RU treatment leads to a decrease of Akt and in turn in its phosphorylated form. RPMI 8226 and LP-1 cells display a constitutive activity of p65 NF- $\kappa B$ subunit binding on DNA (not shown). RU treatment has no effects on pl $\kappa B$, the inhibitor of NF- $\kappa B$, but up-regulates this form in RPMI 8226. RU has no effects on the MAPK, ERK1/2 and JNK pathways. On the Jak/Stat3 pathway, preliminary results indicate that in RPMI 8226 cells, RU down-regulates pTyr705-Stat3. Experiments are ongoing to determine whether the inhibition of the Jak/Stat3 is necessary for apoptosis to occur.

both the mitochondrial and endoplasmic reticulum death pathways in MM cells. ER ligands act in synergy with conventional molecules used in the treatment of cancer, such as dexamethasone, and bortezomib (Jordan 2007, Jordan \& Brodie 2007), and encouraging preliminary results for MM xenografts (Maillard et al. 2006) and MM patients (Fassas et al. 2001) provide a rationale for the use of AEs in the clinical treatment of MM. AE compounds may be of greater value for the treatment than the original restriction of their use to $\mathrm{E}_{2}$-dependent BCs might suggest. The chief unresolved question concerns the involvement of ER in mediating the anti-proliferative effects of AEs. Our working hypothesis is that in both BC and MM cells, AE-mediated cell cycle arrest is ER dependent, whereas apoptosis is ER independent. ERs require various co-regulatory proteins for their function (Hall \& McDonnell 2005), and the cell-specific expression of these molecules may account for differences in the actions of different ER antagonists. In addition, the discovery of membrane ER-triggered effects and crosstalk with growth factors, NF- $\mathrm{B}$ and kinase cascade signalling (Gee et al. 2003, Kalaitzidis \& Gilmore 2005, Martin et al. 2005, Nicholson et al. 2005) has greatly complicated our view of the mechanism of action of ER ligands. However, due to the large tissue distribution of ERs (and mainly ER $\beta$ ), it is likely that AEs could have some positive or negative effects on various other cancers such as uterine, ovary, lung and colon cancers due to crosstalk with the above-mentioned pathways

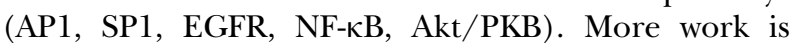
clearly required to improve our understanding of the 
activities of ER ligands regulation of the balance existing between $\mathrm{ER} \alpha$ and $\mathrm{ER} \beta$.

\section{Acknowledgements}

Supported by the Ligue Nationale contre le Cancer Comités du Cher de l'Indre et des Hauts de Seine (to J-M R), Comités de la Manche et du Calvados (to B S), the Association pour la Recherche sur le Cancer (fellowship to C B and A S). The authors declare no conflict of interest that would prejudice impartiality of the research.

\section{References}

Altucci L, Addeo R, Cicatiello S, Dauvois S, Parker MG, Truss M, Beato M, Sica F, Bresciani F \& Weisz A 1996 17 $\beta$-Estradiol induces cyclin D1 gene transcription, p36D1-p34cdk4 complex activation and p105Rb phosphorylation during mitogenic stimulation of $\mathrm{G}(1)$-arrested human breast cancer cells. Oncogene 12 2315-2324.

Ameller T, Marsaud V, Legrand P, Gref R \& Renoir JM 2003 In vitro and in vivo biologic evaluation of long-circulating biodegradable drug carriers loaded with the pure antiestrogen RU 58668. International Journal of Cancer 106 446-454.

Biswas DK, Singh S, Shi O, Pardee AB \& Iglehart JD 2005 Crossroads of estrogen receptor and NF-кB signaling. Science's STKE 2005 pe27.

Bommert K, Bargou RC \& Stuhmer T 2006 Signalling and survival pathways in multiple myeloma. European Journal of Cancer 42 $1574-1580$.

Burow ME, Weldon CB, Tang Y, McLachlan JA \& Beckman BS 2001 Oestrogen-mediated suppression of tumour necrosis factor alphainduced apoptosis in MCF-7 cells: subversion of Bcl-2 by antioestrogens. Journal of Steroid Biochemistry and Molecular Biology 78 409-418.

Caldon CE, Daly RJ, Sutherland RL \& Musgrove EA 2006 Cell cycle control in breast cancer cells. Journal of Cellular Biochemistry $\mathbf{9 7}$ 261-274.

Campbell RA, Bhat-Nakshatri P, Patel NM, Constantinidou D, Ali S \& Nakshatri H 2001 Phosphatidylinositol 3-kinase/AKT-mediated activation of estrogen receptor alpha: a new model for anti-estrogen resistance. Journal of Biological Chemistry 276 9817-9824.

Cariou S, Donovan JC, Flanagan WM, Milic A, Bhattacharya N \& Slingerland JM 2000 Down-regulation of p21WAF1/CIP1 or p27Kip1 abrogates antiestrogen-mediated cell cycle arrest in human breast cancer cells. PNAS 97 9042-9046.

Carroll JS, Prall OW, Musgrove EA \& Sutherland RL 2000 A pure estrogen antagonist inhibits cyclin E-Cdk2 activity in MCF-7 breast cancer cells and induces accumulation of p130-E2F4 complexes characteristic of quiescence. Journal of Biological Chemistry $\mathbf{2 7 5}$ 38221-38229.

Carroll JS, Lynch DK, Swarbrick A, Renoir JM, Sarcevic B, Daly RJ, Musgrove EA \& Sutherland RL 2003 p27(Kip1) induces quiescence and growth factor insensitivity in tamoxifen-treated breast cancer cells. Cancer Research 63 4322-4326.

Castro-Rivera E, Samudio I \& Safe S 2001 Estrogen regulation of cyclin D1 gene expression in ZR-75 breast cancer cells involves multiple enhancer elements. Journal of Biological Chemistry 276 30853-30861.

Chauhan D, Catley L, Hideshima T, Li G, Leblanc R, Gupta T, Slatter M, Richardson P, Schlossman R, Podar K et al. 2002 2-Methoxyestradiol overcomes drug resistance in multiple myeloma cells. Blood 100 2187-2194.

Chen LF \& Greene WC 2004 Shaping the nuclear action of NF-кB. Nature Reviews. Molecular Cell Biology 5 392-401.
Cuendet M, Christov K, Lantvit DD, Deng Y, Hedayat S, Helson L, McChesney JD \& Pezzuto JM 2004 Multiple myeloma regression mediated by bruceantin. Clinical Cancer Research 10 1170-1179.

Dahlman-Wright K, Cavailles V, Fuqua SA, Jordan VC, Katzenellenbogen JA, Korach KS, Maggi A, Muramatsu M, Parker MG \& Gustafsson JA 2006 International Union of Pharmacology. LXIV. Estrogen receptors. Pharmacological Reviews 58 773-781.

Dinda S, Sanchez A \& Moudgil V 2002 Estrogen-like effects of thyroid hormone on the regulation of tumor suppressor proteins, p53 and retinoblastoma, in breast cancer cells. Oncogene 21 761-768.

Doisneau-Sixou SF, Sergio CM, Carroll JS, Hui R, Musgrove EA \& Sutherland RL 2003 Estrogen and antiestrogen regulation of cell cycle progression in breast cancer cells. Endocrine Related Cancer 10 179-186.

Duong V, Boulle N, Daujat S, Chauvet J, Bonnet S, Neel H \& Cavailles V 2007 Differential regulation of estrogen receptor alpha turnover and transactivation by Mdm2 and stress-inducing agents. Cancer Research 67 5513-5521.

Ellis CA, Vos MD, Wickline M, Riley C, Vallecorsa T, Telford WG, Zujewskil J \& Clark GJ 2003 Tamoxifen and the farnesyl transferase inhibitor FTI-277 synergize to inhibit growth in estrogen receptorpositive breast tumor cell lines. Breast Cancer Research and Treatment 78 59-67.

Enmark E \& Gustafsson JA 1999 Oestrogen receptors - an overview. Journal of Internal Medicine 246 133-138.

Falkenstein E, Tillmann HC, Christ M, Feuring M \& Wehling M 2000 Multiple actions of steroid hormones-a focus on rapid, nongenomic effects. Pharmacological Reviews 52 513-556.

Fassas AB, Rapoport AP, Bolanos-Meade J, Shanholtz C, Cottler-Fox M \& Tricot G 2001 Tamoxifen-based treatment induces clinically meaningful responses in multiple myeloma patients with relapsing disease after autotransplantation. Leukemia and Lymphoma $\mathbf{4 2}$ $1323-1328$

Fattman CL, An B, Sussman L \& Dou QP 1998 p53-independent dephosphorylation and cleavage of retinoblastoma protein during tamoxifen-induced apoptosis in human breast carcinoma cells. Cancer Letters 130 103-113.

Faulds MH, Olsen H, Helguero LA, Gustafsson JA \& Haldosen LA 2004 Estrogen receptor functional activity changes during differentiation of mammary epithelial cells. Molecular Endocrinology 18 412-421.

Foster JS \& Wimalasena J 1996 Estrogen regulates activity of cyclindependent kinases and retinoblastoma protein phosphorylation in breast cancer cells. Molecular Endocrinology 10 488-498.

Foster JS, Henley DC, Bukovsky A, Seth P \& Wimalasena J 2001 Multifaceted regulation of cell cycle progression by estrogen: regulation of Cdk inhibitors and Cdc25A independent of cyclin D1-Cdk4 function. Molecular and Cellular Biology 21 794-810.

Foster JS, Fernando RI, Ishida N, Nakayama KI \& Wimalasena J 2003 Estrogens down-regulate p27Kipl in breast cancer cells through Skp2 and through nuclear export mediated by the ERK pathway. Journal of Biological Chemistry 278 41355-41366.

Frasor J, Danes JM, Komm B, Chang KC, Lyttle CR \& Katzenellenbogen BS 2003 Profiling of estrogen up- and down-regulated gene expression in human breast cancer cells: insights into gene networks and pathways underlying estrogenic control of proliferation and cell phenotype. Endocrinology 144 4562-4574.

Frasor J, Chang EC, Komm B, Lin CY, Vega VB, Liu ET, Miller LD, Smeds J, Bergh J \& Katzenellenbogen BS 2006 Gene expression preferentially regulated by tamoxifen in breast cancer cells and correlations with clinical outcome. Cancer Research $\mathbf{6 6}$ 7334-7340.

Gauduchon J, Gouilleux F, Maillard S, Marsaud V, Renoir JM \& Sola B 2003 The selective estrogen receptor modulator 4-hydroxy tamoxifen induces G1 arrest and apoptosis of multiple myeloma cell lines. Annals of the New York Academy of Sciences 1010 321-325.

Gauduchon J, Gouilleux F, Maillard S, Marsaud V, Renoir JM \& Sola B 2005 The 4-hydroxytamoxifen inhibits proliferation of multiple 
myeloma cells in vitro and in vivo through down-regulation of c-Myc, up-regulation of p27Kipl and modulation of Bcl-2 family members. Clinical Cancer Research 11 2345-2354.

Gee JM, Harper ME, Hutcheson IR, Madden TA, Barrow D, Knowlden JM, McClelland RA, Jordan N, Wakeling AE \& Nicholson RI 2003 The antiepidermal growth factor receptor agent gefitinib (ZD1839/Iressa) improves antihormone response and prevents development of resistance in breast cancer in vitro. Endocrinology 144 5105-5117.

Glaros S, Atanaskova N, Zhao C, Skafar DF \& Reddy KB 2006 Activation function-1 domain of estrogen receptor regulates the agonistic and antagonistic actions of tamoxifen. Molecular Endocrinology 20 996-1008.

Gompel A, Somai S, Chaouat M, Kazen A, Kloosterboer HJ, Beusman I, Forgez P, Mimoun M \& Rostene W 2000 Hormonal regulation of apoptosis in breast cells and tissues. Steroids 65 593-598.

Gottardis MM, Robinson SP, Satyaswaroop PG \& Jordan VC 1988 Contrasting actions of tamoxifen on endometrial and breast tumor growth in the athymic mouse. Cancer Research 48 812-815.

Green S, Kumar V, Theulaz I, Wahli W \& Chambon P 1988 The N-terminal DNA-binding 'zinc finger' of the oestrogen and glucocorticoid receptors determines target gene specificity. $E M B O$ Journal 7 3037-3044.

Grimaldi CM, Cleary J, Dagtas AS, Moussai D \& Diamond B 2002 Estrogen alters thresholds for B cell apoptosis and activation. Journal of Clinical Investigation 109 1625-1633.

Hall JM \& McDonnell DP 1999 The estrogen receptor beta-isoform $(\mathrm{ER} \beta)$ of the human estrogen receptor modulates ER $\alpha$ transcriptional activity and is a key regulator of the cellular response to estrogens and antiestrogens. Endocrinology 140 5566-5578.

Hall JM \& McDonnell DP 2005 Coregulators in nuclear estrogen receptor action: from concept to therapeutic targeting. Molecular Interventions 5 343-357.

Hanstein B, Djahansouzi S, Dall P, Beckman MW \& Bender HG 2004 Insights into the molecular biology of the estrogen receptor define novel therapeutic targets for breast cancer. European Journal of Endocrinology 150 243-255.

Hayden MS \& Ghosh S 2004 Signaling to NF-кB. Genes and Development 18 2195-2224.

Heldring N, Pike A, Andersson S, Matthews J, Cheng G, Hartman J, Tujague M, Strom A, Treuter E, Warner M et al. 2007 Estrogen receptors: how do they signal and what are their targets. Physiological Reviews 87 905-931.

Hideshima T, Mitsiades C, Tonon G, Richardson PG \& Anderson KC 2007 Understanding multiple myeloma pathogenesis in the bone marrow to identify new therapeutic targets. Nature Reviews. Cancer 7 585-598.

Holst F, Stahl PR, Ruiz C, Hellwinkel O, Jehan Z, Wendland M, Lebeau A, Terracciano L, Al-Kuraya K, Janicke F et al. 2007 Estrogen receptor alpha (ESR1) gene amplification is frequent in breast cancer. Nature Genetics 39 655-660.

Hur J, Chesnes J, Coser KR, Lee RS, Geck P, Isselbacher KJ \& Shioda T 2004 The Bik BH3-only protein is induced in estrogen-starved and antiestrogen-exposed breast cancer cells and provokes apoptosis. PNAS 101 2351-2356.

Hurd C, Khattree N, Dinda S, Alban P \& Moudgil VK 1997 Regulation of tumor suppressor proteins, p53 and retinoblastoma, by estrogen and antiestrogens in breast cancer cells. Oncogene 15 991-995.

Jamerson MH, Johnson MD \& Dickson RB 2004 Of mice and Myc: c-Myc and mammary tumorigenesis. Journal of Mammary Gland Biology and Neoplasia 9 27-37.

Janicke RU, Sprengart ML, Wati MR \& Porter AG 1998 Caspase-3 is required for DNA fragmentation and morphological changes associated with apoptosis. Journal of Biological Chemistry $\mathbf{2 7 3}$ 9357-9360.

Jordan VC 2004 Selective estrogen receptor modulation: concept and consequences in cancer. Cancer Cell 5 207-213.
Jordan VC 2007 SERMs: meeting the promise of multifunctional medicines. Journal of the National Cancer Institute 99 350-356.

Jordan VC \& Brodie AM 2007 Development and evolution of therapies targeted to the estrogen receptor for the treatment and prevention of breast cancer. Steroids 72 7-25.

Jordan VC, Lewis JS, Osipo C \& Cheng D 2005 The apoptotic action of estrogen following exhaustive antihormonal therapy: a new clinical treatment strategy. Breast 14 624-630.

Kalaitzidis D \& Gilmore TD 2005 Transcription factor cross-talk: the estrogen receptor and NF- $\mathrm{KB}$. Trends in Endocrinology and Metabolism 16 46-52.

Kallio A, Zheng A, Dahllund J, Heiskanen KM \& Harkonen P 2005 Role of mitochondria in tamoxifen-induced rapid death of MCF-7 breast cancer cells. Apoptosis 10 1395-1410.

Kandouz M, Lombet A, Perrot JY, Jacob D, Carvajal S, Kazem A, Rostene W, Therwath A \& Gompel A 1999 Proapoptotic effects of antiestrogens, progestins and androgen in breast cancer cells. Journal of Steroid Biochemistry and Molecular Biology 69 463-471.

Kuiper GG, Enmark E, Pelto-Huikko M, Nilsson S \& Gustafsson JA 1996 Cloning of a novel receptor expressed in rat prostate and ovary. PNAS 93 5925-5930.

Leung LK, Do L \& Wang TT 1998 Regulation of death promoter Bak expression by cell density and 17 beta-estradiol in MCF-7 cells. Cancer Letters 124 47-52.

Lewis JS, Meeke K, Osipo C, Ross EA, Kidawi N, Li T, Bell E, Chandel NS \& Jordan VC 2005 Intrinsic mechanism of estradiol-induced apoptosis in breast cancer cells resistant to estrogen deprivation. Journal of the National Cancer Institute 97 1746-1759.

Lilling G, Nordenberg J, Rotter V, Goldfinger N, Peller S \& Sidi Y 2002 Altered subcellular localization of p53 in estrogen-dependent and estrogen-independent breast cancer cells. Cancer Investigation 20 509-517.

Lindberg MK, Moverare S, Skrtic S, Gao H, Dahlamn-Wright K, Gustafsson JA \& Ohlsson C 2003 Estrogen receptor (ER)- $\beta$ reduces $\mathrm{ER} \alpha$-regulated gene transcription, supporting a 'ying yang' relationship between ER $\alpha$ and ER $\beta$ in mice. Molecular Endocrinology 17 203-208.

Liu MM, Albanese C, Anderson CM, Hilty K, Webb P, Uht RM, Price RH Jr, Pestell RG \& Kushner PJ 2002 Opposing action of estrogen receptors alpha and beta on cyclin D1 gene expression. Journal of Biological Chemistry 277 24353-24360.

Liu W, Konduri SD, Bansal S, Nayak BK, Rajasekaran SA, Karuppayil SM, Rajasekaran AK \& Das GM 2006 Estrogen receptor-alpha binds p53 tumor suppressor protein directly and represses its function. Journal of Biological Chemistry 281 9837-9840.

Lonard DM \& O'Malley BW 2007 Nuclear receptor coregulators: judges, juries, and executioners of cellular regulation. Molecular Cell 27 691-700.

Luo J, Manning BD \& Cantley LC 2003 Targeting the PI3K-Akt pathway in human cancer: rationale and promise. Cancer Cell 4 257-262.

Maillard S, Ameller T, Gauduchon J, Gougelet A, Gouilleux F, Legrand P, Marsaud V, Fattal E, Sola B \& Renoir JM 2005 Innovative drug delivery nanosystems improve the anti-tumor activity in vitro and in vivo of antiestrogens in human breast cancer and multiple myeloma. Journal of Steroid Biochemistry and Molecular Biology 94 111-121.

Maillard S, Gauduchon J, Marsaud V, Gouilleux F, Connault E, Opolon P, Fattal E, Sola B \& Renoir JM 2006 Improved antitumoral properties of pure antiestrogen RU 58668-loaded liposomes in multiple myeloma. Journal of Steroid Biochemistry and Molecular Biology $10067-78$.

Mandlekar S, Yu R, Tan TH \& Kong AN 2000 Activation of caspase-3 and c-Jun NH2-terminal kinase-1 signaling pathways in tamoxifeninduced apoptosis of human breast cancer cells. Cancer Research 60 5995-6000.

Martin LA, Farmer I, Johnston SR, Ali S \& Dowset M 2005 Elevated ERK1/ERK2/estrogen receptor cross-talk enhances estrogenmediated signaling during long-term estrogen deprivation. EndocrineRelated Cancer 12 S75-S84. 
Matthews J, Wihlen B, Tujague M, Wan J, Sttrom A \& Gustafsson JA 2006 Estrogen receptor (ER) $\beta$ modulates ER $\alpha$-mediated transcriptional activation by altering the recruitment of c-Fos and c-Jun to estrogen-responsive promoters. Molecular Endocrinology 20 534-543.

Medina KL, Strasser A \& Kincade PW 2000 Estrogen influences the differentiation, proliferation, and survival of early B-lineage precursors. Blood 95 2059-2067.

Michalides R, Griekspoor A, Balkenende A, Verwoerd D, Janssen L, Jalink K, Floore A, Velds A, van't Veer L \& Neefjes J 2004 Tamoxifen resistance by a conformational arrest of the estrogen receptor alpha after PKA activation in breast cancer. Cancer Cell 5 597-605.

Molina J, Masso F, Paez A, Mendez C, Rodriguez E, Mandoki JJ, Diaz de Leon L \& Montano LF 1999 Differential effect of estradiol on antibody secretion of murine hybridomas. Hybridoma 18 377-383.

Molinari AM, Bontempo P, Schiavone EM, Tortora V, Verdiccio MA, Napolitano M, Nola E, Montcharmont B, Medici N, Nigro V et al. 2000 Estradiol induces functional inactivation of p53 by intracellular redistribution. Cancer Research 60 2594-2597.

Moss RL, Gu Q \& Wong M 1997 Estrogen: nontranscriptional signaling pathway. (discussion 68-9) Recent Progress in Hormone Research 52 33-68.

Mosselman S, Polman J \& Dijkema R 1996 ER $\beta$ : identification and characterization of a novel human estrogen receptor. FEBS Letters 392 49-53.

Muraoka RS, Lenferink AE, Simpson J, Brantley DM, Roebuck LR, Yakes FM \& Arteaga CL 2001 Cyclin-dependent kinase inhibitor p27(Kip1) is required for mouse mammary gland morphogenesis and function. Journal of Cell Biology 153 917-932.

Musgrove EA, Hamilton JA, Lee CS, Sweeney KJ, Watts CK \& Sutherland RL 1993 Growth factor, steroid, and steroid antagonist regulation of cyclin gene expression associated with changes in T-47D human breast cancer cell cycle progression. Molecular and Cellular Biology 13 3577-3587.

Nagarkatti N \& Davis BA 2003 Tamoxifen induces apoptosis in Fas + tumor cells by upregulating the expression of Fas ligand. Cancer Chemotherapy and Pharmacology 51 284-290.

Nakshatri H, Bhat-Nakshatri P, Martin DA, Goulet RJJr \& Sledge GW Jr 1997 Constitutive activation of NF- $\mathrm{B}$ during progression of breast cancer to hormone-independent growth. Molecular and Cellular Biology 17 3629-3639.

Nicholson RI, Hutcheson IR, Britton D, Knowlden JM, Jones HE, Harper ME, Hiscox SE, Barrow D \& Gee JM 2005 Growth factor signalling networks in breast cancer and resistance to endocrine agents: new therapeutic strategies. Journal of Steroid Biochemistry and Molecular Biology 93 257-262.

Obrero M, Yu DV \& Shapiro DJ 2002 Estrogen receptor-dependent and estrogen receptor-independent pathways for tamoxifen and 4-hydroxytamoxifen-induced programmed cell death. Journal of Biological Chemistry 277 45695-45703.

Olivier S, Close P, Castermans E, de Leval L, Tabruyn S, Chariot A, Malaise M, Merville MP, Bours V \& Franchimont N 2006 Raloxifeneinduced myeloma cell apoptosis: a study of nuclear factor- $\kappa \mathrm{B}$ inhibition and gene expression signature. Molecular Pharmacology 69 $1615-1623$.

O'Malley BW 2005 A life-long search for the molecular pathways of steroid hormone action. Molecular Endocrinology 19 1402-1411.

Osborne CK \& Schiff R 2005 Estrogen-receptor biology: continuing progress and therapeutic implications. Journal of Clinical Oncology 23 $1616-1622$.

Otsuki T, Yamada O, Kurebayashi J, Moriya T, Sakaguchi H, Kunisie H, Yata K, Uno M, Yawata Y \& Ueki A 2000 Estrogen receptors in human myeloma cells. Cancer Research 60 1434-1441.

Planas-Silva MD \& Weinberg RA 1997 Estrogen-dependent cyclin E-cdk2 activation through p21 redistribution. Molecular and Cellular Biology 17 4059-4069.
Popov VM, Wang C, Shirley LA, Rosenberg A, Li S, Nevalainen M, Fu M \& Pestell RG 2007 The functional significance of nuclear receptor acetylation. Steroids 72 221-230.

Prall OW, Sarcevic B, Musgrove E, Watts CK \& Sutherland RL 1997 Estrogen-induced activation of Cdk4 and Cdk2 during G1-S phase progression is accompanied by increased cyclin D1 expression and decreased cyclin-dependent kinase inhibitor association with cyclin E-Cdk2. Journal of Biological Chemistry 272 10882-10894.

Prall OW, Rogan EM, Musgrove EA, Watts CK \& Sutherland RL 1998 c-Myc or cyclin D1 mimics estrogen effects on cyclin E-Cdk2 activation and cell cycle reentry. Molecular and Cellular Biology 18 4499-4508.

Prall OW, Carroll JS \& Sutherland RL 2001 A low abundance pool of nascent p21WAF1/Cip1 is targeted by estrogen to activate cyclin E*Cdk2. Journal of Biological Chemistry 276 45433-45442.

Pratt MA, Bishop TE, White D, Yasvinski G, Menard M, Niu NY \& Clarke R 2003 Estrogen withdrawal-induced NF- $\mathrm{B}$ activity and bcl-3 expression in breast cancer cells: roles in growth and hormone independence. Molecular and Cellular Biology 23 6887-6900.

Ray A, Prefontaine KE \& Ray P 1994 Down-modulation of interleukin-6 gene expression by 17 beta-estradiol in the absence of high affinity DNA binding by the estrogen receptor. Journal of Biological Chemistry 269 12940-12946.

Renoir JM, Stella B, Ameller T, Connault E, Opolon P \& Marsaud V 2006 Improved anti-tumoral capacity of mixed and pure anti-oestrogens in breast cancer cell xenografts after their administration by entrapment in colloidal nanosystems. Journal of Steroid Biochemistry and Molecular Biology 102 114-127.

Riggins RB, Bouton AH, Liu MC \& Clarke R 2005a Antiestrogens, aromatase inhibitors, and apoptosis in breast cancer. Vitamins and Hormones 71 201-237.

Riggins RB, Zwart A, Nehra R \& Clarke R $2005 b$ The nuclear factor kappa B inhibitor parthenolide restores ICI 182,780 (Faslodex; fulvestrant)-induced apoptosis in antiestrogen-resistant breast cancer cells. Molecular Cancer Therapeutics 4 33-41.

Sabbah M, Courilleau D, Mester J \& Redeuilh G 1999 Estrogen induction of the cyclin D1 promoter: involvement of a cAMP response-like element. PNAS 96 11217-11222.

Sayeed A, Konduri SD, Liu W, Bansal S, Li F \& Das GM 2007 Estrogen receptor alpha inhibits p53-mediated transcriptional repression: implications for the regulation of apoptosis. Cancer Research 67 $7746-7755$

Sherr CJ \& Roberts JM 1999 CDK inhibitors: positive and negative regulators of G1-phase progression. Genes and Development 13 1501-1512.

Shim GJ, Wang L, Andersson S, Nagy N, Kis LL, Zhang Q, Makela S, Warner M \& Gustafsson JA 2003 Disruption of the estrogen receptor beta gene in mice causes myeloproliferative disease resembling chronic myeloid leukemia with lymphoid blast crisis. PNAS 100 6694-6699.

Shim GJ, Gherman D, Kim HJ, Omoto Y, Iwase H, Bouton D, Kis LL, Andersson CT, Warner M \& Gustafsson JA 2006 Differential expression of oestrogen receptors in human secondary lymphoid tissues. Journal of Pathology 208 408-414.

Slingerland J \& Pagano M 2000 Regulation of the cdk inhibitor p27 and its deregulation in cancer. Journal of Cellular Physiology 183 10-17.

Smithson G, Couse JF, Lubahn DB, Korach KS \& Kincade PW 1998 The role of estrogen receptors and androgen receptors in sex steroid regulation of B lymphopoiesis. Journal of Immunology 161 $27-34$.

Smolnikar K, Loffek S, Schulz T, Michna H \& Diel P 2000 Treatment with the pure antiestrogen faslodex (ICI 182780) induces tumor necrosis factor receptor 1 (TNFR1) expression in MCF-7 breast cancer cells. Breast Cancer Research and Treatment 63 249-259.

Sola B \& Renoir JM 2006 Antiestrogenic therapies in solid cancers and multiple myeloma. Current Molecular Medicine 6 359-368.

Sola B \& Renoir JM 2007 Estrogenic or antiestrogenic therapies for multiple myeloma? Molecular Cancer 659. 
Somai S, Chaouat M, Jacob D, Perrot JY, Rostene W, Forgez P \& Gompel A 2003 Antiestrogens are pro-apoptotic in normal human breast epithelial cells. International Journal of Cancer 105 607-612.

Song RX \& Santen RJ 2003 Apoptotic action of estrogen. Apoptosis 8 $55-60$.

Song RX, Fan P, Yue W, Chen Y \& Santan RJ 2006 Role of receptor complexes in the extranuclear actions of estrogen receptor alpha in breast cancer. Endocrine-Related Cancer 13 (Suppl 1) S3-S13.

Strasser A, O'Connor L \& Dixit VM 2000 Apoptosis signaling. Annual Review of Biochemistry 69 217-245.

Strom A, Hartman J, Foster JS, Kietz S, Wimalasena J \& Gustafsson JA 2004 Estrogen receptor beta inhibits $17 \beta$-estradiol-stimulated proliferation of the breast cancer cell line T47D. PNAS101 1566-1571.

Sun M, Paciga JE, Feldman RI, Yuan Z, Coppola D, Lu YY, Shelley SA, Nicosia SV \& Cheng JQ 2001 Phosphatidylinositol-3-OH Kinase (PI3K)/AKT2, activated in breast cancer, regulates and is induced by estrogen receptor alpha $(\mathrm{ER} \alpha)$ via interaction between $\mathrm{ER} \alpha$ and PI3K. Cancer Research 61 5985-5991.

Thiantanawat A, Long BJ \& Brodie AM 2003 Signaling pathways of apoptosis activated by aromatase inhibitors and antiestrogens. Cancer Research 63 8037-8050.

Treon SP, Teoh G, Urashima M, Ogata A, Chauhan D, Webb IJ \& Anderson KC 1998 Anti-estrogens induce apoptosis of multiple myeloma cells. Blood 92 1749-1757.

Tsai EM, Wang SC, Lee JN \& Hung MC 2001 Akt activation by estrogen in estrogen receptor-negative breast cancer cells. Cancer Research $\mathbf{6 1}$ $8390-8392$.
Watson PH, Pon RT \& Shiu RP 1991 Inhibition of c-myc expression by phosphorothioate antisense oligonucleotide identifies a critical role for c-myc in the growth of human breast cancer. Cancer Research 51 3996-4000.

Watts CK, Brady A, Sarcevic B, DeFazio A, Musgrove EA \& Sutherland RL 1995 Antiestrogen inhibition of cell cycle progression in breast cancer cells in associated with inhibition of cyclin-dependent kinase activity and decreased retinoblastoma protein phosphorylation. Molecular Endocrinology 9 1804-1813.

Zhang GJ, Kimijima I, Onda M, Kanno M, Sato H, Watanabe T, Tsuchiya A, Abe R \& Takenoshita S 1999 Tamoxifen-induced apoptosis in breast cancer cells relates to down-regulation of bcl-2, but not bax and bcl-X(L), without alteration of p53 protein levels. Clinical Cancer Research 5 2971-2977.

Zheng A, Kallio A \& Harkonen P 2007 Tamoxifen-induced rapid death of MCF-7 breast cancer cells is mediated via extracellularly signalregulated kinase signaling and can be abrogated by estrogen. Endocrinology 148 2764-2777.

Received in final form 18 December 2007

Accepted 14 January 2008

Made available online as an Accepted Preprint

14 January 2008 